\title{
Man's Eternal "Tilt" in Arrabal's L'Architecte et l'empereur d'Assyrie
}

\author{
Robin Rash \\ Lambuth University, Jackson (Tennessee)
}

Tn a bizarre interview at the Limelight Café in New York in 1960, a mischievous Fernando Arrabal was asked by Ann Morrisset what sort of person his mother was: "Very religious," he intoned, "Very. But now she is crazy. She lay on top of me when I was tied to the bed. She writes to me all the time since I left Madrid begging me to return, but I don't answer her. Why do you always speak of my mother?" (p. 73)

Despite the young Arrabal's propensity for flippant comments concerning his past, this otherwise offhand remark is a reflection of the literary Arrabal. In his brief response the author suggests many of the major themes one finds in his plays: religion, incest, bondage, love, abandonment and, of course, the omnipresent image of the mother, the recurrent Arrabalesque nightmare of the castrating virago and evil receptacle of lust. Having emphasized his mother's religious feelings, Arrabal concludes that "now she is crazy," the implication being that religion has led to her mental "tilt." But, to paraphrase Arrabal, why are we always asking about his mother?

The mother image in Arrabal's works has been treated at length by numerous scholars. ${ }^{1}$ The importance these critics attach to the mother figure in Arrabal's L'Architecte cannot be denied, but the religious aspects of the play are of even greater significance.

The "tilt" scene in L'Architecte, for example, underlines the conflict between the eternal (man's spirit) and the absurdity (cruelty, panic) of man's present condition. Arrabal equates art with life; his mother's mental imbalance is paralleled by an emperor driven to madness by his last-second failure to prove the existence of God by reaching a thousand points on a pinball machine. It is not clear whether religion has failed man, i.e., is inadequate to man's needs, or if man is the failure. Only the quest itself and its resultant madness seem to concern Arrabal. I shall examine the failure of the emperor to beat this juvenile arcade game, for the emperor's failure 
is also man's. In his search for the eternal, man is eternally doomed to experience an inexplicable "tilt."

In a work so thematically eclectic, it might at first appear presumptuous to claim to have found a unifying force, a thematic unity which binds the grotesque, sublime and ritualistic motifs in the play. But these seemingly disparate elements reinforce rather than negate the work's common denominator - man's endless, absurd and, ultimately, ineffectual quest for the eternal. Arrabal presents us with a repeating cycle of: 1) an initial stage of innocence (virginity); 2) the oppression of civilization (knowledge, hence guilt) and: 3 ) rejection of civilization and guilt and the return to the initial stage of innocence. ${ }^{2}$ Consistent with this thematic triad, I have divided up my analysis of the play to represent this cycle.

Critic Peter Podol has theorized that the stage directions for the opening scene in the first act, including airplane noises, flashes of light and explosions, are suggestive of the violent origin of man. The opening effects, he states, are indicative of "the birth process itself" (p. 74). But if, as Podel suggests, this crash is a birth, Arrabal has reversed the process whereby a child is born ignorant of the world around it. This "baby" is no tabula rasa. Instead, he carries a suitcase, calls himself an emperor, and has, as Arrabal states, "une certaine élégance guindée" (p. 349). The emperor requests assistance and states that he is the sole survivor of the crash. As Podel implies, this violent "accident," this luminous explosion, is man. But the birth of this full-grown baby who fights to "garder son sang-froid" (p. 349) stands in marked contrast to the two thousand-year-old architect whose infantile babble and fright remind one of the nursery. The architect's terror and attempt to bury his head in the sand are perhaps not unlike the reactions of a primitive tribesman upon seeing an airplane for the first time. The so-called "civilized man" has come - albeit by accident, a crash - to civilize the barbaric "natural" man, the man forgotten by time whom, states the emperor, "Dieu a chiée dans l'océan par méprise" (p. 350). ${ }^{3}$

The emperor immediately attempts to bring religion to the architect. As he dreamily recalls civilization, the emperor forces the architect to his knees and proceeds to explain his "life" prior to the crash. Gesturing as though he were a god, the emperor rises slowly and states in a grandiloquent fashion, "Je me levais aux premières lueurs de l'aube, toutes les églises, toutes les synagogues, tous les temples faisaient sonner leurs trompettes. Le jour commençaient à poindre. Mon père venait m'éveiller suivi d'un régiment de violonistes. Ah! la musique. Quelle merveille!n (p. 351) Then, in the midst of this majestic posturing, he quickly turns 
toward the architect with an alarmed look and demands, "As-tu fait cuire les saucisses aux lentilles?" (p. 351) This humorous interlude, so typical of Arrabal's theatre, serves as the reader's/spectator's introduction to the absurdity of man's striving for the eternal. Despite his "civilization," we see that the emperor is barely removed from the stone age, his primary concern being his belly, not eternity. The preparation of the pork and beans takes precedence over immortality. The emperor creates an illusory world, a cerebral creation of the spirit, to hide his true identity and origin. The unfolding of the drama leads to what critic Robert Zyromski calls "a psychedelic exposition, a ritual self-examination and self-sacrifice, the difference being the Emperor's ultimate realization of his guilt and his own demand for self-punishment" (p. 206).

The emperor's hallucinatory distortion of perception would, indeed, suggest a desire or need to escape from reality. But it is a reality based less, perhaps, on Jung's notion of the "terrible mother of all abominations" than on the knowledge of the inescapable and absurd repetition of a life based on seeking the eternal (Podol, p. 74). The cyclical recurrence of life, death, and (re)birth does not lead man any closer to proof of the existence of a higher being. The search for incontestable evidence which would give meaning to our existence is doomed to failure. Regardless of how "civilized" man may become, the search for ultimate knowledge will be thwarted, i.e., our pinball machine will always tilt at 999 points (if not before) when all we need is a thousand. Man, like the emperor, is relegated to the childish game of drawing by lots to see, as Arrabal states, "qui allait racheter l'humanité" (p. 352).

The first act of the play is dominated by games. The lessons the emperor gives to the guileless architect range from playing horsey to sadomasochistic torture. Having failed in his efforts to prove the existence of God, the emperor deludes himself into thinking he is a god. At one point he becomes furious with the architect over a trifle and commands him to die at his feet. When the architect fails to respond on cue, the exasperated emperor vents his frustration by stomping on ants - a senseless act of revenge denoting man's impotence, his total inability to control his life, much less find a reason for his existence. The bizarre and the extraordinary actions of the play's two characters merge the world of the imagination (of the word) with the real world (the body). This step is achieved by a "ceremony of initiation," what critic Gloria Orenstein calls the "Panic world of confusion, in which the image becomes the catalyst of the event and the event stimulates the creation of new images" (p. 239). The image of changing sexual roles, for example, often serves as a catalyst for humorous events and bizarre images. In one scene the emperor 
assumes a woman's voice and tries to seduce his friend: "Oh! mon amour, m'aimes-tu?" (p. 355) Reality, however, intrudes when he tries to raise his trousers as though they were the skirt he envisions he is wearing. He snaps: "Merde! les jupons!n (p. 356)

The emperor's buffoonery and duality of gender resemble the Greek god Pan whose whimsical nature and duality of form (man-goat) make him the perfect source of Arrabal's "Panic." Inspired by Artaud's theatre of cruelty, Arrabal's Panic theatre "is at once a serious exposition of philosophical and aesthetic principles and a parody of attempts at organized literary movements and theories" (Podel, p. 59). Arrabal paid homage to his spiritual predecessor by stating: "Artaud a tout prévu. Il a parle de l'Empereur d'Assyrie. Il a parlé de panique" (Schifres, p. 72).

The logic behind Artaud's call for a theatre of cruelty closely resembles the circular plot of L'Architecte. ${ }^{4}$ Artaud contends that "our spiritual anarchy and intellectual disorder is a function of the anarchy of everything else, or rather, everything else is a function of this anarchy" (Artaud, p. 79). The spiritual anarchy found in L'Architecte is the basis for the psychological dysfunctions and intellectual disorders of its characters. Ironically, despite anarchy, there is no true freedom, no liberation from the oppression of anarchy. Man is free to be free, i.e., to live in a world of chaos, lawlessness and turmoil. But he is not free to escape from the crushing forces of life. The emperor is very aware of being a prisoner of flesh and blood. His actions typify Artaud's conclusion that "we are not free . . . and the sky can still fall on our heads. And the theatre has been created to teach us that" (Artaud, p. 79). Arrabal's theatre does precisely this. The sky not only can fall on our heads, it does so with depressing regularity. The two plane crashes at the beginning and end of the play are indicative of our failure to rise above the human condition. ${ }^{5}$

The gruesome, Guignolesque treatment accorded the religious ritual of transubstantiation in the final act illuminates this failure. The emperor commands the architect to dress up as his mother and eat him. The bones and blood of the emperor replace the bread and wine of the Eucharist. This cannibalistic sacrifice, however, provides no transformation into the presence of Christ, but an all too human metamorphosis of the architect into the emperor, yet another beginning in the endless cycle of love, death, and rebirth through transmutation. At first the architect is puzzled by the change. He states: "Tiens, je ne me souviens de rien ... C'est un beau foullis dans ma tête ... Au fait, quelle est ma religion?» (p. 424) The "new" emperor can remember nothing, not even his religion, but he quickly 
concludes: "Enfin il vaut mieux que je laisse ça de côté» (p. 424). The innocent perversity of the architect is transformed into the guilt-ridden perversity of the emperor; the gulf that separates them is enormous. The emperor has created God but failed in his attempt to prove his existence, a proof which would have validated his own existence. His failure brings about his guilt and need to condemn what he had sought in vain to prove. The emperor reflects upon what he perceives as his "accidental" loss at pinball: "Sans l'ivrogne," he states, "je marquais automatiquement dix points de plus. La partie. Dieu. Les anges. Le ciel et l'enfer. Les bons et les méchants. Le saint prépuce et ses miracles ..." (p. 390). In short, he would have won it all. His failure leads to a revulsion of religion. Having created a monster, the emperor, as civilized man, must now try to destroy him by denying him his divinity. He states: "Tout ce qu'll y a d'atroce, de nauseabond, de fétide, de vulgaire, se trouve résumé en un mot: Dieu." (p. 391) To show his irreverence the emperor even sings his abominations to an opera aria:

"Merde pour Dieu. Merde à sa divine image.

Merde à son omniprésencen (p.416) .

Arrabal's mockery of religion is particularly effective with the sequencing of the nuclear annihilation scene into the emperor's roast-in-hell speech. In the initial scene our two protagonists are the leaders of two warring nations; they have ordered the nuclear annihilation of one half of their opponent's population. After a resounding success in mass destruction, they congratulate their respective military forces by telling them they can now claim "honneurs de la guerre. Pour un monde meilleur" (p. 359). In the scene which immediately follows, the protagonists engage in a brief discussion about religion. When the emperor hears that his primitive friend has never been baptized, he roars a fire-and-brimstone reproach: "Tu cours à ta perdition. Pendant toute l'éternité tu vas rôtir jour et nuit et l'on choisira les plus belles diablesses pour t'exiter, mais elles t'enfonceront des fers rouges dans lanus" (p. 361). One can only conclude that being the agent of death on a massive scale will be praised by humanity, whereas not having had some water sprinkled on your forehead as a baby will condemn you to eternal damnation.

If only half the world is destroyed in this initial atomic confrontation, Arrabal completes the destruction in a subsequent scene. Here, the emperor enrages the leader of a superpower by calling him a homosexual, a "vieux paillard" and "petit 
coquin." In the nuclear holocaust which follows there are no human survivors. The architect and emperor now appear as apes, calling out for "Papa Darwin" while passionately embracing each other. The architect - transformed into a female ape - concludes simply: "il faudra recommencer" (p. 370).

This scene epitomizes the vicious and endless repetition of man's struggle to conquer his guilt and to come to terms with his place in the cosmos. In a universe he did not create and cannot begin to comprehend, man continually confronts himself through subterfuge and deceit. He is free to the extent that anarchy permits, but his freedom is limited by his own humanity. ${ }^{6}$ Arrabal's hero displays what Camus describes in The Myth of Sisyphus as "the mind's deepest desire ... which parallels man's unconscious feeling in the face of his universe: it is an insistence upon familiarity ... Understanding the world for a man is reducing it to the human, stamping it with his seal" (p. 13). In L'Architecte et l'empereur d'Assyrie Arrabal has stamped with his seal the absurdity, chaos, panic, and cruelty of life. The characters' guilt, anxiety and expiation emphasize the author's pessimism (Donahue, p. 45). The emperor, despite his confession and expiation, is not purged of his sins. The ritualistic and polymorphic aspects of the play combine the profane with the sacred, an alliance which parallels the complementary relationship between the architect and the emperor. The nobel savage and the civilized man are also the ravenous cross-dressing cannibal and the zealous pinball crusader. Each develops an awareness of the self and mutual trust of the other. "Both characters come to the truth [about the other], both learn, yet they both find their corruption in the other" (Zyromski, p. 218). Civilized man disappears inside the stomach of the savage only to be reborn by becoming his opposite.

Finally, the encounter upon the stage between the architect and the emperor, these two "passionate manifestations", results in, as Artaud describes it, "something as entire, true, even decisive, as, in life, the encounter of one epidermis with another in a timeless debauchery" (p. 79). 


\section{Notes}

${ }^{1}$ For criticism of the Oedipus complex in Arrabal's L'Architecte, see Camille Amary's "Le Jardin des délices" in Fernando Arrabal: théâtre VI. (Christian Bourgois, 1969), p. 9-12. For a negative critique of Arrabal's mother image, see Phyllis $Z$. Boring's “Arrabal's Mother Image," Kentucky Quarterly Review 15 (1968), p. 285-92. In his article, "The Psychological Base of Arrabal's L'Architecte et l'empereur d'Assyrie," French Review 45 (special issue) 4 (1972), p. 123-136, Charles $R$. Lyons uses Jung's Symbols of Transformation to analyze the female unconscious in Arrabal's work.

${ }^{2}$ Even the earliest critics of Arrabal understood the dramatist's mocking contemporaneity. Jacques Guicharnaud observes: "Beckett, Ionesco, Adamov (first period), Charlie Chaplin, the Marx Brothers (especially Harpo), Kafka - such influences or possible associations make it clear that Arrabal is a modern playwright ... [whose] modernism is strongly colored by the most nightmarish aspects of a certain brand of surrealism," (p. 116). In "Forbidden Games: Arrabal," Yale French Studies 29 (1962), p. 116-120, Geneviève Serreau concludes: "The universe Arrabal's characters inhabit is incontestably today's world, and our international James Deans will probably identify themselves with his heroes whose very existence is a challenge to the established moral values, to the Order which sets up the sclerosed structures under which our civilization is gently collapsing" (p. 67-68). In "A New Comic Style: Arrabal," Evergreen Review 4.15 (1960), p. 61-69.

${ }^{3}$ The reader may be shocked by such vulgarity, but as critic André Clavel notes: "Tout le théâtre d'Arrabal est dans cette formule. Un théâtre fou, brutal, clinquant, joyeusement provocateur. Un potlach dramaturgique ou la carcasse de nos sociétés 'avancées' se trouve carbonisée sur la rampe festive d'une révolution permanente," in Dictionnaire des littératures de langue française, tome 1. (Paris: Bordas, 1987), p. 84.

${ }^{4}$ As Martin Esslin indicates, Arrabal's L'Architecte "derives its title from a passage in Artaud's writings on the theatre of cruelty, in which he speaks of the cruelty of 'Assyrian emperors' who sent each other the cutoff ears and noses of their enemies" (p. 291) in The Theatre of the Absurd, (Peregrine: New York, 1987).

5 Janet Winecoff Diaz contends that Arrabal's "teatro panico" is a mixture of comedy and tragedy, of farce and existential alienation. "Arrabal appears to believe," Diaz 
states, "that human existence is absurd because we are born without asking to be born, and die without seeking death, we live between birth and death trapped within our bodies and the limits of our reason, in a complex of self-defeating paradoxes, a check and balance of power and impotence, knowledge and ignorance, attunement and alienation" (p. 153) in "Theatre and Theories of Fernando Arrabal," Kentucky Romance Quarterly 16.2 (1969), p. 143-154.

${ }^{6}$ Allan Thiher asserts: "Arrabal's characters often have a personal hatred of God; yet, their anger with Him is often a result of His refusal to exist. It is difficult to revolt against the absent Father" (p. 181). In "Arrabal and the Theatre of Obsession," Modern Drama 13.2 (1970), p. 174-183.

\section{Works Cited}

Arrabal, Fernando. L'Architecte etl'empereur d'Assyrie. L'avant-garde théâtrale. Ed.

Thomas Bishop. Lexington, Mass.: D.C. Heath, 1970. p. 347-430.

Artaud, Antonin. The Theatre and Its Double. New York: Grove, 1958.

Camus, Albert. The Myth of Sisyphus. New York: Vintage, 1955.

Donahue, Thomas John. The Theatre of Fernando Arrabal: A Garden of Earthly

Delights. New York: New York UP, 1980.

Morrissett, Ann. "Dialogue With Arrabal." Evergreen Review, 4 (1960). p. 70-75.

Orenstein, Gloria Feman. The Theatre of the Marvelous. New York: New York UP, 1975.

Podel, Peter L. Fernando Arrabal. Boston: Twayne, 1978.

Schifres, Alain. Entretiens avec Arrabal. Paris: Pierre Belfond, 1969.

Zyromski, Robert. "A Critical Study of Selected Plays of Fernando Arrabal." Diss.

Bowling Green State Univ., 1969. 